\title{
LYSOSOMAL ACID LIPASE DEFICIENCY IN A 6-YEAR-OLD CHILD: CASE REPORT
}

\author{
Oleksandra SHULHAI ${ }^{1 凶}$, Anna KABAKOVA ${ }^{2}$, Anna-Mariia SHULHAI ${ }^{3}$ \\ ${ }^{1}$ Department of Children's Diseases with Paediatric Surgery, I. Horbachevsky Ternopil National Medical \\ University of the Ministry of Health of Ukraine, Ternopil, Ukraine \\ ${ }^{2}$ Regional Children's Clinical Hospital, Ternopil, Ukraine \\ ${ }^{3}$ Department of Paediatrics No2, I. Horbachevsky Ternopil National Medical University of the Ministry of \\ Health of Ukraine, Ternopil, Ukraine
}

\author{
Received 01 July 2020, Accepted 05 Sept 2020 \\ https://doi.org/10.31688/ABMU.2020.55.4.19
}

\begin{abstract}
Introduction. Cholesteryl ester storage disease or lysosomal acid lipase deficiency is a rare severe congenital enzyme pathology of lysosomal storage disorders. This pathology is linked with LIPA gene impairing mutations on chromosome 10 in locus 10q24-q25, coding lysosomal acid lipase enzyme (cholesterol ester hydrolase). The lysosomal acid lipase enzyme is involved in cellular fat metabolism, thus causing hepatic, vascular, nervous system, and adrenal glands damage.
\end{abstract}

Case presentation. We report the case of a six-year-old boy with cholesteryl ester storage disease, who was admitted to the hospital with physical retardation, hepatosplenomegaly, impaired lipid profile, revealing an increased very-low-density lipoprotein cholesterol level and decreased high-density lipoprotein cholesterol level, dyslipidaemia, and hypercholesterolemia with highly increased atherogenic index, elevated bilirubin and aminotransferases.

Conclusions. Severe hepatic impairment may occur in patients with cholesteryl ester storage disease in the absence of replacement therapy with acid

\section{Résumé}

La carence de ferment lipolytique chez un enfant âgé de 6 ans: rapport de cas

Introduction. La maladie d'accumulation d'esters de cholestérol, ou déficit en lipase acide lysosomiale, est une fermentopathie héréditaire grave et rare liée aux maladies à accumulation lysosomiale. La survenue de cette pathologie est associée à des mutations dommageables du gène LIPA, situé sur le dixième chromosome au locus 10q24-q25 et codant pour une enzyme lipase acide lysosomiale (cholestérol ester hydrolase). L'enzyme lipase acide lysosomiale (LLL) est impliquée dans le métabolisme des graisses dans les cellules. Ainsi, quand elle est déficiente, le foie, les vaisseaux sanguins, le système nerveux et les glandes surrénales sont endommagés.

Rapport du cas. Enfant de 6 ans présentant des troubles lipidiques, se manifestant par une augmentation du cholestérol à lipoprotéines de très basse densité (LDL), une diminution du cholestérol à lipoprotéines de haute densité (HDL), ce qui a stimulé le développement de la dyslipidémie et 
lipase fermentation. The possibility of a timely diagnosis raises the likelihood of a quality treatment and prolongation of life in patients with lysosomal storage diseases.

Keywords: lysosomal acid lipase deficiency, cholesteryl ester storage disease, children, lipid metabolism disorders.

\section{List of abbreviations:}

DLAL - deficiency of lysosomal acid lipase, LIPA - lipase A, LAL - Lysosomal acid lipase, LDL - low-density lipoproteins, ERT - enzyme replacement therapy, CESD - cholesteryl ester storage disease, CMV - cytomegalovirus, EBV - Epstein-Barr virus, ALT - alanine aminotransferase, AST - aspartate aminotransferase, NAMS - National Academy of Medical Sciences.

\section{INTRODUCTION}

Rare (orphan) diseases associated with congenital metabolic disorders are among the causes of hepatomegaly and liver function anomalies in children. Deficiency of lysosomal acid lipase (DLAL) is a rare genetic enzymatic pathology of lysosomal storage diseases, namely sphingolipidoses, with a prevalence of 1:40 000-1:300 000 of live-born children, according to various data ${ }^{1,2}$. The emergence of this enzyme pathology is due to damaging mutations in LIPA gene on chromosome 10 in locus 10q23.2-q23.3, coding lysosomal acid lipase enzyme (cholesteryl ester hydrolase). DLAL is transmitted by autosomal-recessive type of inheritance, a sick child (homozygote or compound heterozygote) inheriting a single mutated gene from parents. In families with parents as disease carriers, the risk of abnormal childbirth is $25 \%$ per pregnancy ${ }^{3,4}$. In Ukraine, six children with this pathology have been registered so $f_{a}{ }^{5}$. Therefore, it is crucial for a paediatrician to give a timely diagnosis, which would allow to prescribe an enzyme replacement therapy, improving life quality and expectancy of the child.

Lysosomal acid lipase (LAL) enzyme is involved in the cellular fat metabolism, its deficiency causing damage to the liver, vessels, nervous system, and adrenal glands. Normally, low-density lipoproteins (LDL), linked to the receptor at the cellular surface with cholesteryl esters, penetrate the cell and blend with lysosome, where LAL enzyme hydrolysis cholesterol and triglycerides esters to free cholesterol and fatty acids. Intracellular storage of free cholesterol is fraught with the suppression of LDL effect on the receptors, decreased cholesterol synthesis, and ultimately, de l'hypercholestérolémie. Les caractéristiques cliniques de cet enfant ne sont pas assez spécifiques: retard de développement physique, hépatite, splénomégalie, qui ont pris un certain temps pour la mise du diagnostic de cette pathologie spécifiée.

Conclusions. Une altération hépatique grave peut survenir chez les patients atteints de cholestérolose hépatique en l'absence d'une thérapie de substitution à ferment lipolytique. La possibilité d'un diagnostic en temps utile est la probabilité d'un traitement de qualité et d'une prolongation de la vie des patients atteints de cholestérolose hépatique.

Mots-clés: défaut de lipase acide lysosomiale, maladie du stockage des esters de cholestérol, enfants, troubles du métabolisme des lipides.

formation of phospholipids and triglycerides is inhibited due to accumulation of fatty acids in the cell ${ }^{6-8}$.

There is no specific treatment for DLAL, symptomatic treatment is the only one available. Recombinant human enzyme replacement therapy (ERT), that is life-long infusion of acid lipase, is the most important in Wolman's disease and cholesteryl ester storage disease (CESD) 9 . Administration of pathogenic ERT in the early stages of disease is promising in terms of improving health-related quality of child's life and preventing subsequent disability and lethality, but it is unavailable for prescription in Ukraine ${ }^{10}$.

\section{Case report}

A 6-year-old boy, born in 2011, who lives in Ternopil, Ukraine, was admitted to the $2^{\text {nd }}$ Paediatric Department of the Ternopil Children's Regional Hospital, Ukraine, with complaints of right abdominal pain and in the navel area, occurring regardless of food intake, fatigue during physical exercise.

From the past medical history, parents did not notice from the birth any changes in the state of the child's health, except of colds. Since 2014, after an acute intestinal infection (with a severe diarrheal syndrome, dehydration), abdominal pain, unrelated to diet or exercise, periodically appeared and the paediatrician found hepatomegaly. At the end of October 2015, the child was diagnosed with acute bronchitis and received two courses of antibiotics on an outpatient basis within a few weeks, without clinical improvement. In early December 2015, an obstructive respiratory component added to long-term cough, and the treatment did not have a significant clinical effect; as a result, an outpatient paediatrician prescribed neophylline. Within one 
hour after neophylline intake, jaundice appeared (known to be one of the side effects of this drug cholestatic hepatitis) and the boy was hospitalized for one month in the infectious department of the Ternopil City Children's Hospital, diagnosed with unidentified cause moderate hepatitis, bronchitis complicated by obstructive syndrome. Hepatitis A, $\mathrm{B}, \mathrm{C}$ markers, detection of antibodies to cytomegalovirus (CMV) and Epstein-Barr virus (EBV) have been screened several times, with negative results. Given the pronounced persistent hepatomegaly, resistant to hepato-protectors, and the need for a differential diagnosis of jaundice, in mid-December 2015 a number of laboratory examinations have been performed, that revealed anaemia, total bilirubin $72.4 \mu \mathrm{mol} / \mathrm{L}$ (direct bilirubin $32.6 \mu \mathrm{mol} / \mathrm{L}$, indirect bilirubin 39.8 $\mu \mathrm{mol} / \mathrm{L})$, ALT $117 \mathrm{IU} / \mathrm{L}$, AST $97 \mathrm{IU} / \mathrm{L}$. Pilocarpine test was negative; blood coagulation tests were normal. Abdominal ultrasonography revealed enlarged liver (right lobe $128 \mathrm{~mm}$, left lobe $106 \mathrm{~mm}$ ), parenchyma fine-grained, homogeneous, vascular pattern depleted, portal vein-diameter $8 \mathrm{~mm}$, in the gall bladder - an echogenic sediment. The spleen was 106x60 mm, homogeneous. Computed tomography scan showed a diffusely enlarged liver, low density, enlarged spleen. Chest X-ray: right-sided pneumonia. Blood tests for $\operatorname{IgG}$ antibodies to toxocariasis and ascaris were negative.

Detoxification and hepato-protector therapy (containing phosphatidylcholine and dimethylphenyl-anthranilic acid compound) has been prescribed, but aminotransferases increased: ALT $224 \mathrm{IU} / \mathrm{L}$, AST 98 IU/L. Treatment with ursodeoxycholic acid $10 \mathrm{mg} / \mathrm{kg} /$ day was initiated, with improvement of the biochemical blood tests: total bilirubin $22.4 \mu \mathrm{mol} / \mathrm{L}$ (direct bilirubin $11.4 \mu \mathrm{mol} / \mathrm{L}$, indirect bilirubin 10.0 $\mu \mathrm{mol} / \mathrm{L})$, ALT $74 \mathrm{IU} / \mathrm{L}$, AST $50 \mathrm{IU} / \mathrm{L}$. The boy was discharged in a relatively satisfactory clinical condition, but hepatomegaly and splenomegaly persisted. After a few months, the laboratory tests showed: total bilirubin $6.3 \mu \mathrm{mol} / \mathrm{L}$, ALT 21.2 IU/L, AST 35.8 IU/L.

Given the frequent respiratory infections of their child, in February 2017 the parents consulted an immunologist, who confirmed the hepatosplenomegaly. In addition to baseline biochemical tests, other tests have been performed: lipidogram - cholesterol 8.34 $\mathrm{mmol} / \mathrm{L}$ (normal upper value $6.2 \mathrm{mmol} / \mathrm{L}$ ), HDL 1.0 $\mathrm{mmol} / \mathrm{L}$ (no risk > $1.45 \mathrm{mmol} / \mathrm{L}$ ), LDL $6.93 \mathrm{mmol} / \mathrm{L}$ (normal upper value $4.89 \mathrm{mmol} / \mathrm{L}$ ), triglycerides 1.36 $\mathrm{mmol} / \mathrm{L}$ (normal upper value $5 \mathrm{mmol} / \mathrm{L}$ ), atherogenic index 7.34 (normal upper value 3), total bilirubin $4.4 \mu \mathrm{mol} / \mathrm{L}$, ALT $33 \mathrm{IU} / \mathrm{L}$, AST $42 \mathrm{IU} / \mathrm{L}$. After these results, the immunologist sends the patient to a regional children's hospital for paediatric gastroenterological evaluation.

On March 2017, during admission in The Ternopil Children's Regional Hospital, the boy's general condition was as follows: physical development under 25 percentile, dark circles under eyes, subicteric sclera, vascular asterisks on his hands, the tongue coated white, abdomen distended, soft and painful on palpation in the right hypochondrium, hepatomegaly (Fig. 1), and splenomegaly. The blood tests revealed: cholesterol $6.6 \mathrm{mmol} / \mathrm{L}, \mathrm{HDL}$-chol 0.69 $\mathrm{mmol} / \mathrm{L}$, LDL-chol $6.36 \mathrm{mmol} / \mathrm{L}$, triglycerides 7.9 $\mathrm{mmol} / \mathrm{L}$, atherogenic index 8.56, total bilirubin 11.7 $\mu \mathrm{mol} / \mathrm{L}$, ALT $50.8 \mathrm{IU} / \mathrm{L}$, AST $49.1 \mathrm{IU} / \mathrm{L}$, methaemoglobin $8.4 \%$ (normal upper value $2 \%$ ). The dynamics of changes in cytolysis tests is presented in Fig. 2.

The gastroenterologist prescribed treatment with ursodeoxycholic acid $20 \mathrm{mg} / \mathrm{kg} /$ day and polyunsaturated fatty acids (omega 3) $800 \mathrm{mg} /$ day. The rapid disease course, persistent hepatosplenomegaly, despite treatment with hepato-protectors, cholagogues and choleretics, changes of the lipid profile indicated a lipid metabolism disorder and gave rise to the suspicion of a rare genetic pathology. The child was referred to the Hepatology Centre of the "Institute of Paediatrics, Obstetrics and Gynaecology of the

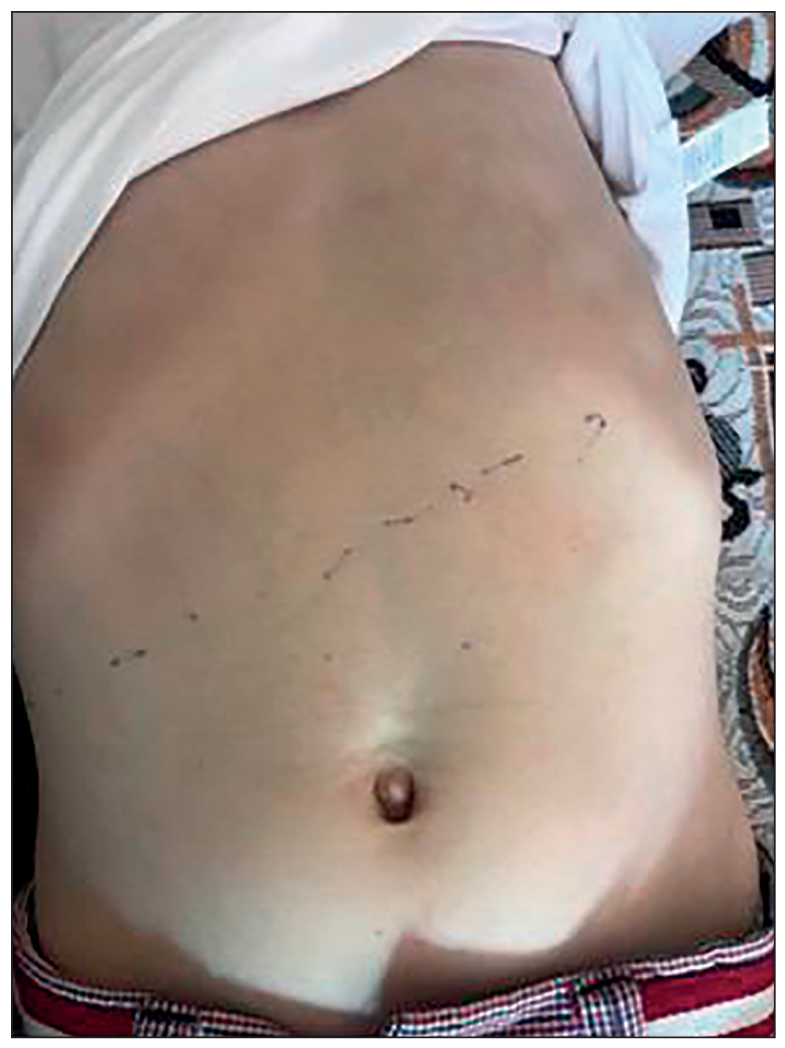

Figure 1. Picture of the abdomen (hepatomegaly is marked on the picture) 


\section{Dynamics of ALT / AST in a patient with cholesteryl ester storage disease}

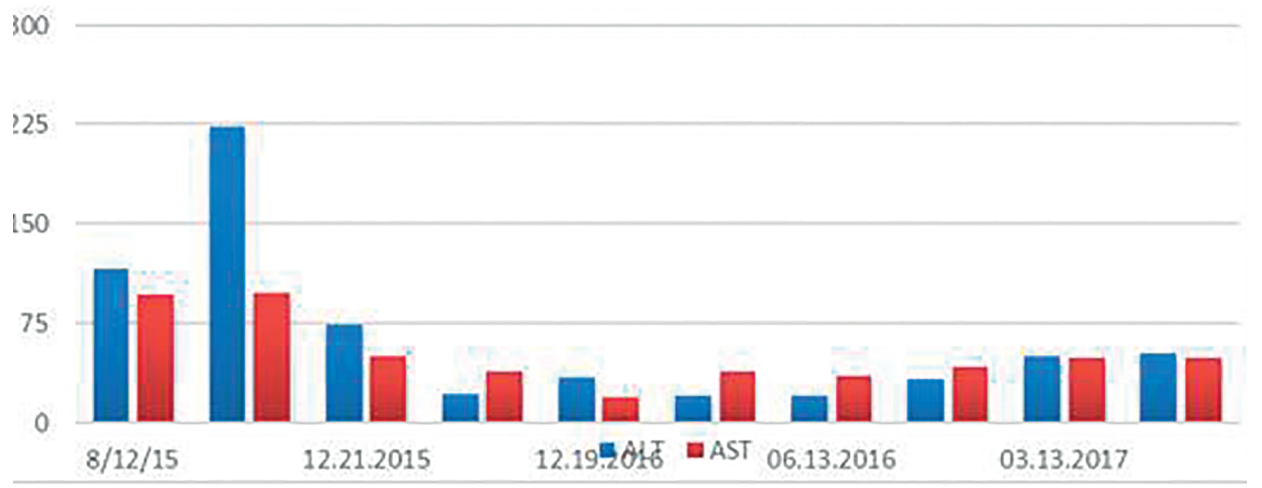

Figure 2. Dynamics of ALT, AST in a patient with cholesteryl ester storage disease

NAMS of Ukraine" and to the Centre of Orphan Diseases of the National Children's Specialized Hospital "Ohmatdyt" of the Ministry of Health of Ukraine. The genetic study had the following results: a complete sequence of the LIPA gene was performed along with exons of 2 to 10 of adjacent genes and anthropic regions. Exon 8 revealed a single nucleotide G to A substitution at the 894 chodon in the homozygous state (listed in the international database on human mutations as pathogenic CS951467). The results of enzymatic tests revealed that the activity of acid lipase (in a dry blood spot) was 0.03 (at a rate of 0.16-1.8 nM/h/spot), i.e. sharply reduced. The child was diagnosed with a genetic disorder of sphingolipid metabolism and other lipid storage disorders - deficiency of lysosomal acid lipase (cholesteryl ester storage disease). The treatment was only symptomatic, because the recombinant form of the enzyme lysosomal acid lipase, which is required for ERT to prevent liver fibrosis, is not registered in Ukraine and is unavailable for prescription in our country.

\section{Discussion}

Deficiency of lysosomal acid lipase is a metabolic lipid storage disease caused by mutations in the lysosomal acid lipase (LIPA) gene. The LIPA gene contains instructions for producing the enzyme lysosomal acid lipase $e^{9 \cdot 11}$. The defect in LIPA gene is located on chromosome 10q23.2-q23.3 and comprises 10 exons and their mutations result in the DLAL. Cholesteryl ester storage disease is a rare autosomal recessive disease, it occurs with higher frequencies in populations where consanguinity is more com$\operatorname{mon}^{11,12}$.

In children, lysosomal acid lipase deficiency manifests in one of two ways: an early presentation (in the first year of life) and a late one (at an older age). There are two phenotypes of DLAL: Wolman's disease, first described in 1956 by a group of authors and named after Wolman, was discovered during the histological experiment, and CESD, first described by Fredrickson in 1963. In the early (infantile) form of DLAL (Wolman's disease) in new-borns and small children, the complete absence of LAL enzyme activity was found, thus predicting a complicated disease course. The early (infantile) form of DLAL (Wolman's disease) in infants and young children presents an almost complete absence (less than $1 \%$ ) of LIPA enzyme activity, so the course of the disease is fulminant and in the absence of diagnosis the disease leads to death within first 6 months of life. This involves nourishment problems, nausea, vomiting, liver and spleen severe damage and enlargement, as well as malabsorption syndrome, resulting in physical growth and development retardation. The late form of DLAL, namely CESD, is characterized by sharply reduced (1-12\%) activity of the acid lipase enzyme, so the onset of the initial clinical symptoms can be different. In the later DLAL (CESD) stages, children and adults present dyslipidaemia, hepatomegaly and liver steatosis, increased aminotransferases. The cause of mortality in the majority of CESD patients is hepatic failure, while about $8 \%$ of them die from bleeding from oesophageal varicose veins. In many cases, the diagnosis based on biochemical blood tests and ultrasound liver examination is not infrequent ${ }^{11-14}$.

In patients with DLAL, cells are overfilled with lysosomes with undestroyed molecules due to the insufficient activity of the enzyme; hepatocytes reveal an elevated very-low-density lipoprotein (VLDL) cholesterol level together with a decreased high-density lipoprotein (HDL) cholesterol level; cholesterol endocytosis is intensified through LDL receptors, thus 
stimulating the development of dyslipidaemia and hypercholesterolemia ${ }^{12,15}$. Cholesteryl esters deposition in the liver leads to small-drop fatty dystrophy, causing liver damage due to steatosis. An increased serum level of aminotransferases, ALT and AST, is a marker of damage. Cholesteryl esters deposition in the cells of gastric mucosa results in malabsorption syndrome, with diarrhoea and steatorrhea, as well as excessive bacterial growth and tympanites. Spleen enlargement may be due to accumulation of cholesterol esters in the cells, progressive hepatic pathology and portal hypertension ${ }^{13,14,16}$.

Thus, referring to complaints and medical history of the patients with suspicion of DLAL, attention should be paid to the child with: 1) enlarged liver and spleen; 2) developmental physical and mental difficulties, general weakness and undue fatigability; 3) pain in the epigastrium, liquid, fatty stool (diarrhoea, steatorrhea); 4) jaundice, ascites, oesophageal varicose veins; 5) abdominal distention; 6) adrenal calcification; 6) aggravated family history (cases of illness or death from liver disease). These children have higher levels of aminotransferases, hypercholesterolemia, hypertriglyceridemia, elevated alkaline phosphatase, anaemia, abnormal urine potassium concentration ${ }^{11,16}$.

No specific treatment of DLAL is available, symptomatic therapy is the only one. However, ERT, that is life-long infusion of acid lipase, is the most important in Wolman's disease and CESD. In 2013, the first report on the effectiveness of recombinant human lysosomal acid lipase in children with DLAL was published ${ }^{17}$. In December 2015, the American Food and Drug Administration approved sebelipase alpha as a first-line therapy for people with lysosomal acid deficiency. Sebelipase alpha contains the rhLAL protein, which replaces the partially active or inactive LAL protein in patients with DLAL. However, it is not registered in Ukraine and is unavailable for prescription in our country. Other treatment is symptomatic and directed toward specific symptoms, as in our patient.

A definitive diagnosis of cholesteryl ester storage disease can be established in children based on characteristic symptoms and by measuring acid lipase activity in leucocytes and fibroblasts. Molecular genetic testing for mutations in the LIPA gene, which can be carried out using extracted DNA or by nested PCR from dried blood spots, are useful ${ }^{18,19}$.

Transplant of hematopoietic stem cells possessing sufficient lysosomal acid level, from a healthy donor to a sick child, may be used in patients with Wolman's disease. However, the data are scanty ${ }^{17,18}$. Gene therapy is one of the possible future therapies for DLAL ${ }^{19,20}$.

\section{Conclusions}

The list of orphan diseases that lead to a reduction of life expectancy in children or to their disability, for which treatments exist, but are not always accessible to patients, is steadily increasing. Therefore, when the physicians examine children patients with the following signs and symptoms:

- enlarged liver and spleen;

- delayed physical or neuropsychological development, general weakness, increased fatigue;

- abdominal pain, loose, greasy stools (diarrhoea, steatorrhea);

- jaundice, ascites, varicose veins in the oesophagus;

- indicative medical family history (cases of liver disease or death), it is necessary to rule out a genetic pathology.

DLAL should be included in the differential diagnosis of all patients who have elevated LDL-C, who also may have mildly to moderately decreased HDL-C levels, elevated bilirubin and aminotransferases, and hepatosplenomegaly. Primary care doctors, in the presence of persistent symptoms and signs of diseases, that do not fit into a particular disease, need to be able to suspect a rare pathology and timely guide the patient for an early diagnosis and treatment.

\section{Author Contributions:}

O.S. and A.K. were responsible for the diagnostic procedures, clinical diagnosis, and treatment decisions. O.S. and A.-M.S. wrote the manuscript. All authors have read and agreed to the published version of the manuscript.

\section{Compliance with Ethics Requirements:}

„The authors declare no conflict of interest regarding this article"

„The authors declare that all the procedures and experiments of this study respect the ethical standards in the Helsinki Declaration of 1975, as revised in 2008(5), as well as the national law. Informed consent was obtained from the patient included in the study"

"No funding for this study“

\section{Acknowledgements:}

None

\section{References}

1. Strokova TV, Bagaeva ME, Matinyan IA. Lysosomal acid lipase deficiency. RMJ. 2017; 19:1346-1351.

2. Baranov A, Namazova-Baranova L, Gundobina O, et al. Deficiency of lysosomal acid lipase: clinical recommendations for child health care delivery. Paediatric Pharmacology. 2016;13(3):239-243. 
3. Bernstein D, Hulkova H, Bialer M, Desnick R. Cholesteryl ester storage disease: review of the findings in 135 reported patients with an underdiagnosed disease. J Hepatol. 2013; 58(6):1230-1243.

4. A-Kader H. Lysosomal acid lipase deficiency: a form of nonobese fatty liver disease (NOFDL). Expert Rev Gastroenterol Hepatol. 2017; 7:1-14.

5. Order of the Ministry of Health of Ukraine "On Amendments to the List of rare (orphan) diseases that lead to a reduction in life expectancy of patients or disability and for which there are recognized methods of treatment" [Electronic resource] // number 731 of 29 June 2017 Available at: http://zakon.rada.gov.ua/laws/show/z0910 17\#Text

6. Jeon T, Osborne T. SREBPs: metabolic integrators in physiology and metabolism. Trends Endocrinol Metab. 2012; 23:6572.

7. Horton J, Goldstein J, Brown M. SREBPs: activators of the complete program of cholesterol and fatty acid synthesis in the liver. J Clin Invest. 2002; 109:1125-1131.

8. Tolar J, Petryk A, Khan K, et al. Long-term metabolic, endocrine, and neuropsychological outcome of hematopoietic cell transplantation for Wolman disease. Bone Marrow Transplant. 2009; 43(1):21-7.

9. Sadhukhan M, Saha A, Vara R, Bhaduri B. Infant case of lysosomal acid lipase deficiency: Wolman's disease. BMJ Case Rep. 2014:1-3.

10. Balwani M, Breen C, Enns GM et al. Clinical effect and safety profile of recombinant human lysosomal acid lipase in patients with cholesteryl ester storage disease. Hepatology. 2013; 58(3): 950-957.

11. Pagani F, Pariyarath R, Garcia R, et al. New lysosomal acid lipase gene mutants explain the phenotype of Wolman disease and cholesteryl ester storage disease. J Lipid Res. 1998; 39:1382-1388

12. Elleder M, Chlumska A, Hyanek J, et al. Subclinical course of cholesteryl ester storage disease in an adult with hypercholesterolemia, accelerated atherosclerosis, and liver cancer. J Hepatol. 2000; 32:528-534.

13. Boldrini R, Devito R, Biselli R, et al. Wolman disease and cholesteryl ester storage disease diagnosed by histological and ultrastructural examination of intestinal and liver biopsy. Pathol Res Pract. 2004; 200:231-240.

14. Mayevskaya M, Ivashkin V, Zharkova T, et al. Rare forms of non-alcoholic fatty liver disease: hereditary lysosomal acid lipase deficiency. Russian Journal of Gastroenterology, Hepatology, Coloproctology. 2016; 26(3):41-51.

15. Vesa CM, Popa L, Popa AR, et al. Current data regarding the relationship between type 2 diabetes mellitus and cardiovascular risk factors. Diagnostics. 2020;10(5): 314.

16. Jones S, Bernstein D, Bialer M, et al. Severe and rapid disease course in the natural history of infants with lysosomal acid lipase deficiency. Mol Genet Metab. 2014; 111:57-58.

17. Angelika L. Erwin. The role of sebelipase alpha in the treatment of lysosomal acid lipase deficiency. Therap Adv Gastroenterol. 2017;10(7): 553-562.

18. Krivit W, Peters C, Dusenbery K, et al. Wolman disease successfully treated by bone marrow transplantation. Bone Marrow Transplantation. 2000; 26(5):567-70.

19. Pritchard AB, Strong A, Ficicioglu C. Persistent dyslipidaemia in treatment of lysosomal acid lipase deficiency. Orphanet J Rare Dis. 2020; 15, 58.

20. Rajamohan F, Reyes AR, Ruangsiriluk W, et al. Expression and functional characterization of human lysosomal acid lipase gene (LIPA) mutation responsible for cholesteryl ester storage disease (CESD) phenotype. Protein Expression and Purification. 2015; 110: 22-29. 